\title{
The Influence of Copper Sulphate on Growth, Morphology and on Anatomy of Vegetative Organs of Triticum Aestivum L
}

\author{
Stela-Gabriela JELEA*, Oana-Corina JELEA, Lucia MIHALESCU, Zorica VOȘGAN \\ Department of Chemistry and Biology, Faculty of Science, North University Center at Baia Mare Technical \\ University of Cluj-Napoca, Victoriei Street, No.76, 430122, Baia Mare, Romania \\ *corresponding author, e-mail: stela.jelea@cunbm.utcluj.ro
}

Bulletin USAMV series Agriculture 74(2)/2017

Print ISSN 1843-5246; Electronic ISSN 1843-5386

DOI 10.15835/buasvmcn-agr: 0038

\begin{abstract}
Copper is necessary for the growth and development of plants, but a high concentrations is extremely toxic, resulting in growth inhibition and toxicity symptoms.

In this study we investigated the effects of caryopses immersion of Triticum aestivum L, for 24 hours, at different concentrations of copper sulphate. $\mathrm{CuSO}_{4}$ × $5 \mathrm{H}_{2} 0(0.05 \mathrm{~g} / \mathrm{L}$ - variant V1; $0.1 \mathrm{~g} / \mathrm{L}$ - variant V2; $0.5 \mathrm{~g} / \mathrm{L}$ variant V3; $1 \mathrm{~g} / \mathrm{L}$ - variant $\mathrm{V} 4$ ). The result of metabolic disturbances induced by the treatment of vegetative organs was their growth inhibition in a dose-dependent manner. Our results suggest that caryopses immersion for 24 hours with copper sulphate in a concentration of $0.5 \mathrm{~g} / \mathrm{l}$ and $1 \mathrm{~g} / \mathrm{l}$ induce anatomic and morphological changes in vegetative organs.
\end{abstract}

Keywords: anatomy, copper sulphate, growth, morphology, seedlings

\section{INTRODUCTION}

Copper is an essential micronutrient for plants. Copper's participation in plant development derives from the fact that it has an important role in respiration, photosynthesis, lignification, growth and is a constituent of proteins and enzymes (Kabata-Pendias, 2011; González et al. 2012).

Excess of metals in soil can be harmful to plants. Due to human activities, copper contamination is a problem all over the world. Copper sulphate has been used to fight fungal diseases (Kabata-Pendias, 2011). Long-term applied fungicides allow the accumulation of copper in soil. Metal pollution is a problem due to the penetration of metals in food chains (Shorrocks and Alloway, 1988; Toma et al. 2002).

\section{AIMS AND OBJECTIVES}

The purpose of this study was to assess the effects of the caryopses immersion of Triticum aestivum L, for 24 hours, at different concentrations of $\mathrm{CuSO}_{4} \times 5 \mathrm{H}_{2} 0$. The study aimed to investigate the morphological and anatomical effects caused to vegetative organs developed from immersed caryopses at different concentrations of copper sulfate.

\section{MATERIALS AND METHODS}

The biological material investigated is the seedling of Triticum aestivum $\mathrm{L}$, obtained from seeds immersed for 24 hours in solutions of different concentrations of copper sulphate (V10.05 g/L; V2-0.1 g/L; V3-0.5 g/L, V4-1g/L). Every experiment was repeated two times.

For each experiment there were used twenty caryopses. The experimental values were reported in the control group. Experimental conditions: temperature $22^{\circ}$, humidity $38.30 \%$ and photoperiod 12 to 13 hours. After 14 days, the growth of vegetative organs was appreciated. 
Biometric measurements of seedlings from the treatment variants were compared with the control. The results were statistically processing using Student's T-test. Outliers were eliminated by Chavennet criteria (Snedecor and Cochram 1978; Weber, 1980).

The morphology and anatomy of vegetative organs in the control group and the experimental variants were investigated using a common method in investigations of plant anatomy. Cross sections were performed through vegetative organs, which were then colored with Genevan reagent and analyzed using the Krüss type trinocular microscope and photographed using a Nikon system.

\section{RESULTS AND DISCUSSION}

Morphology. Caryopses immersion for 24 hours with different concentrations of copper sulphate affected roots elongation. Roots seedlings control had values between $10.18 \pm 0.66$ $\mathrm{cm}$ (replication 1) and $11.10 \pm 0.78 \mathrm{~cm}$ (replication 2). Instead, V3 and V4 in experimental variants percentage differences compared to controls were lower by $-8.55 \%$ respectively $-56.98 \%$.

Regarding the aerial part of the seedling, in the first replication it declines from control between $-3.66 \%$ (V1 variant) and $-51.46 \%$ (V4 variant). Declines were also highlighted in the second replication. Reduced seedling is driven mainly by the reduced growth of the root, since it reduces the transport of nutrients to the aerial part.

Anatomy. The control roots seedlings of Triticum aestivum presents a primary structure characteristic of monocots. Roots seedlings of V3 and V4 experimental variants present defense responses, as the hardening and waterproofing cell wall of the epidermis and cortex. Cortical cells present sinuous walls, causing a slight contraction of roots, similar to the metamorphosed contractile roots.

Structural changes that occur at this level affect some aspects of mineral nutrition and are the main cause of seedling growth inhibition.

\section{CONCLUSION}

A comparative analysis of the morphology of seedlings from the variants of treatment, result inhibition of roots process in experimental variants (V3 and V4), causing the death of seedlings about 14 days after germination. The result of metabolic disturbances induced by treatment of vegetative organs was their growth inhibition in a dosedependent manner.

Our results suggest that caryopses immersion for 24 hours with copper sulfate-induced morphological and anatomical changes in vegetative organs, its intensity is dependent upon the concentrations used.

\section{REFERENCES}

1. González A, Chumillas V, Lobo MC (2012). Effect of Zn, Cd and $\mathrm{Cr}$ on growth, water status and chlorophyll content of barley plants (H. vulgare L.) Agr. Sci., 3(4): 572-581.

2. Kabata-Pendias A (2011).Trace elements in soil and plants. $4^{\text {th }}$ ed. CRC Press, Taylor \& Francis Group, New York.

3. Shorrocks VM, Alloway BJ (1988). Copper in plant, animal and human nutrition, Copper. Development Association, Potter Bar (United Kingdom).

4. Snedecor G, Cochram W (1978). Statistical methods, $6^{\text {th }}$ ed. Iowa State Univ. Press. Ames. Iowa.

5. Toma C, Rugină R, Coroliuc A, Coroliuc I (2002). Histo-anatomical researches upon some caulinar metamorphosis. An. Şt. Univ. „Al. I. Cuza” Iaşi, 48:11-18.

6. Weber E (1980). Grundriss der biologishen für Natur Wisbenscaftler. Laudwirte und Mediziner, G. Fischer Verlag, Jena. 